\title{
VALUE ORIENTATIONS OF MODERN MANAGERS
}

\section{Partyko Neonila ${ }^{1}$}

DOI: https://doi.org/10.30525/978-9934-571-89-3_41

The main characteristic of a modern manager is not so much the availability of the necessary theoretical knowledge and the formation of technical techniques. But in the first place, the development of the semantic sphere which includes both professional meanings (personal professional knowledge, professional attitude to the subordinate, professional ideals, norms and values, semantic motives of professional activity), and also developed personal and professional reflection [1, p. 51-52].

The meaning of life can be regarded as the value of extremely high order. First, it is a professional sense of life, which contains an idea of the meaning of human being, about the appointment of man. Secondly, this is the meaning of a professional's life. This aspect concerns the meaning of one's own life (family, profession). For many leaders, the main values are: to find oneself in life, to be "human", to achieve material wealth, and so on.

The problem of value orientations of the modern manager is relevant due to the important problems of the transforming society. The current researches do not cover the topic of value orientations of leaders in Ukraine in a context of both political and socio-economic crisis in the country.

I. D. Bech, a well-known modern Ukrainian psychologist, uses the notion of "personal values", which reflects the fact that the subject is included in social relationships and attitudes. He interprets a person as a sociocultural reality. More precisely, the notion of "personal values" is associated with the development of social values by particular individuals, and hence, the significance, personal meaning of certain objects, events, phenomena, etc. is fixed for a person.

\footnotetext{
${ }^{1}$ Lviv Polytechnic National University, Ukraine
} 
A psychologist S. S. Bubnova distinguishes three hierarchical levels in the system of value orientations of the person. She relates the abstract, most generalized spiritual, social and material values to the first level. Spiritual values, in turn, differentiate into cognitive, aesthetic, humanistic, and other, social - into the values of social respect, social achievements, social activity, etc. The second level, from the author's point of view, is the values that are fixed in life and manifest as the properties of the person. And the third level is the characteristic ways of person's behavior as well as means of realization and consolidation of values-properties.

The purpose of our research is to study the peculiarities of value orientations of contemporary managers in the Ukrainian society. The hypothesis of the research: the value self-determination of contemporary managers depends on their age, marital status and work experience.

Using the Kruskal-Wallis test, it has been established that younger leaders (under $45)$ value health more than older people (46-55 years). Those who are under 35 years of age, compared to 35 years of age, are more likely to appreciate the material wellbeing, happiness of others and value an interesting job, happy family life, honesty (truthfulness, sincerity) less (see Table 1).

Table 1

The differences in the value self-determination of managers by age

\begin{tabular}{|l|c|c|c|c|c|c|}
\hline \multirow{2}{*}{\multicolumn{1}{|c|}{ Values }} & \multicolumn{3}{|c|}{$\begin{array}{c}\text { Age } \\
\text { (rank, median group) }\end{array}$} & \multicolumn{3}{c|}{ Kruskal-Wallis test } \\
\cline { 2 - 7 } & $\begin{array}{c}\text { up to 35 } \\
\text { years old }\end{array}$ & $\begin{array}{c}36-45 \\
\text { years old }\end{array}$ & $\begin{array}{c}46-55 \\
\text { years old }\end{array}$ & $\begin{array}{c}\chi^{2}- \\
\text { distribu- } \\
\text { tion }\end{array}$ & $\begin{array}{c}\text { degrees } \\
\text { of } \\
\text { freedom }\end{array}$ & $\begin{array}{c}\text { Asympt. } \\
\text { value }\end{array}$ \\
\hline health (physical and mental) & 7,2 & 5,8 & 11,0 & 5,823 & 2 & 0,054 \\
\hline interesting job & 12,0 & 9,0 & 3,0 & 6,363 & 2 & 0,042 \\
\hline material well-being & 5,7 & 11,2 & 11,3 & 7,393 & 2 & 0,025 \\
\hline happy family life & 14,7 & 13,3 & 8,5 & 5,255 & 2 & 0,072 \\
\hline happiness of others & 4,4 & 14,3 & 14,5 & 8,596 & 2 & 0,014 \\
\hline honesty (truthfulness, sincerity) & 15,0 & 10,0 & 5,0 & 7,089 & 2 & 0,029 \\
\hline
\end{tabular}

For married leaders, the following values are more important (compared to single/unmarried): public recognition, parenting (good manners). For unmarried leaders, more important values are freedom, rationalism and efficiency in business (see Table 2).

Those who have a low work experience (up to 10 years) value independence (determination) more and happy family life, honesty (honesty, sincerity) less than their more experienced colleagues. Those who worked in a managerial position to 5 years appreciate an interesting job less (see Table 3 ). 
Table 2 The differences in the value self-determination of managers by their marital status

\begin{tabular}{|l|c|c|c|c|c|}
\hline \multirow{2}{*}{ Values } & \multicolumn{2}{|c|}{$\begin{array}{c}\text { Marital status } \\
\text { (rank, median group) }\end{array}$} & \multirow{2}{*}{ U-statistic } & $\mathrm{Z}$ & $\begin{array}{c}\text { Asympt. value } \\
\text { (2-sided) }\end{array}$ \\
\cline { 2 - 4 } & Married & $\begin{array}{c}\text { Single/ } \\
\text { unmarried }\end{array}$ & & & \\
\hline public recognition & 9,6 & 11,3 & 62,500 & $-1,664$ & 0,096 \\
\hline freedom & 14,5 & 9,3 & 58,500 & $-1,840$ & 0,066 \\
\hline parenting (good manners) & 4,6 & 9,2 & 45,500 & $-2,412$ & 0,016 \\
\hline rationalism & 13,3 & 7,3 & 32,500 & $-2,980$ & 0,003 \\
\hline efficiency in business & 7,9 & 4,7 & 53,000 & $-2,092$ & 0,036 \\
\hline
\end{tabular}

Table 3

The differences in the value self-determination of managers by the experience of work

\begin{tabular}{|l|c|c|c|c|c|c|}
\hline \multirow{2}{*}{ Values } & \multicolumn{3}{c|}{$\begin{array}{c}\text { Experience of work } \\
\text { (rank, median group) }\end{array}$} & \multicolumn{3}{c|}{ Kruskal-Wallis test } \\
\cline { 2 - 8 } & 5 years & 10 years & $10+$ years & $\begin{array}{c}\chi^{2}- \\
\text { distribu- } \\
\text { tion }\end{array}$ & $\begin{array}{c}\text { degrees } \\
\text { of } \\
\text { freedom }\end{array}$ & $\begin{array}{c}\text { Asympt. } \\
\text { value }\end{array}$ \\
\hline interesting job & 16,0 & 4,7 & 8,0 & 7,571 & 2 & 0,023 \\
\hline happy family life & 15,5 & 15,0 & 9,2 & 5,727 & 2 & 0,057 \\
\hline $\begin{array}{l}\text { independence (autonomy } \\
\text { resoluteness) }\end{array}$ & 6,3 & 8,0 & 15,3 & 12,531 & 2 & 0,002 \\
\hline honesty (truthfulness, sincerity) & 16,0 & 9,3 & 7,3 & 5,443 & 2 & 0,066 \\
\hline
\end{tabular}

Consequently, the age is the factor of managers' value self-determination. It affects mainly the instrumental values.

By matching the investigated group of managers with a group of subordinates as they identify the terminal values (TVs) and instrumental values (IVs), we have seen that they are statistically significant only in 5 out of 36 values (for Mann-Whitney U-test).

In general, such values as "development", "honesty (truthfulness, sincerity)" are more important for leaders than for the subordinates for whom more important are "beauty of nature and art", "neatness (cleanliness)", "independence (autonomy, resoluteness)".

The next step of our research was to compare the investigated group of managers with the group of subordinates by the degree of their manifestation of TVs and IVs) in each of the social and demographic subgroups (for Mann-Whitney U-test).

Male managers, in contrast to male subordinates, value more "creativity", "tolerance", "honesty (truthfulness, sincerity)" and value less "independence (autonomy, resoluteness)". 
Female leaders, in contrast to female subordinates, value more "honesty (truthfulness, sincerity)" and value less "development and "independence (autonomy, resoluteness)".

The managers under the age of 35, in contrast to subordinates of the same age, value the happiness of others and appreciate less the beauty of nature and art, happy family life, diligence (discipline). And the managers at the age of 36-45, in contrast to subordinates of the same age, value more productive live and appreciate less sensitivity (caring).

The managers at the age of 46-55 years, in contrast to subordinates of the same age, value more interesting work, happy family life, honesty (truthfulness, sincerity) and appreciate less the materially secured life, neatness, independence (determination), irreconcilability to shortcomings, rationalism.

The single/unmarried managers, in comparison with single/unmarried subordinates, value more efficiency in affairs, firm will, honesty (truthfulness, sincerity) and value less precision (cleanliness), independence (determination), irreconcilability to disadvantages. The married leaders, compared to married subordinates, value honesty (truthfulness, sincerity) and value less development and independence (determination).

The managers with a work experience of 5-10 years, compared with subordinates with the same experience, value more health, diligence (discipline), honesty (truthfulness, sincerity) and appreciate sensitivity (caring) less.

The managers with a work experience of more than 10 years, compared with subordinates with the same experience, more appreciate the breadth of views, honesty (truthfulness, sincerity), efficiency in business and less appreciate the beauty of nature and art, neatness, independence (determination), diligence (discipline).

In general, the main factor of the value choice of managers is their age. It affects on the instrumental values.

Consequently, our research found that the managers and subordinates in modern society do not have significant differences in their value orientations.

\section{References:}

1. Voloshyna N.V., Bondar I.V., Shakib O.V. (2017). Cinnisni orijentaciji suchasnykh kerivnykiv $\mathrm{v}$ umovakh transformaciji ukrajinsjkogho suspiljstva [Value orientations of modern managers in the conditions of the transformation of Ukrainian society]. Scientific Herald of Kherson State University. Series "Psychological Sciences", issue 3, vol. 1, pp. 51-56.

2. Voloshyna N.V. (2017). Cinnisni orijentaciji v strukturi osobystosti [Value orientations in the structure of the individual] Psykhologhichni osnovy rozvytku osobystosti: monoghrafija / za zagh. red. V.J. Bocheljuka, za red. M.A. Derghach, N.V. Voloshynoji [Psychological fundamentals of the individuality development]. Zaporizhzhja : Prosvita, pp. 189-208.

3. Musaeljan O.M. (2016). Cmyslozhyttjevi orijentaciji ta osoblyvosti jikh vplyvu na skhyljnistj do autoaghresyvnoji povedinky studentsjkoji molodi [Sense of life orientations and peculiarities of their influence on the tendency to self-aggressive behavior of student youth]. Scientific Herald of Kherson State University. Series "Psychological Sciences", issue 3, vol. 2, pp. 68-75. 